\title{
A Review of Continuing Professional Development (CPD) of Training Competencies for Malaysian Mechanical Industries
}

\author{
Zeti Kasman ${ }^{1, *}$, Affero Ismail ${ }^{2}$, Nadzri Siron ${ }^{1}$ and Noorazman Abd Samad ${ }^{2}$, \\ ${ }^{1}$ Manpower Department, Ministry of Human Resources, 62530 W.P Putrajaya, Malaysia \\ ${ }^{2}$ Faculty of Technical and Vocational Education, Universiti Tun Hussein Onn Malaysia, 86400 Parit Raja Batu Pahat Johor, Malaysia
}

\begin{abstract}
The aim of this paper is to review issues in continuing professional development of vocational training to the mechanical industries. The spectacle of individuals entering the labour market without relevant qualifications is common in Malaysia. There are many who choose to work instead of pursuing further education after secondary school. In the labour market, these individuals are considered to be lowskilled workers because they had no training prior to employment. The role of employers in providing training and education to employees is vital in establishing career development of employees. Employers who contributed to their employees' training funds through Human Resources Development Council would provide opportunities to increase the skills of workers. Based on the Malaysia's Development Plan of Occupational Skill, the issues and challenges that have been identified in producing skilled workers in interpersonal and technical skills. This paper provided an opportunity to examine an enterprise-based approach to skill formation for workers with basic academic qualifications. It presents an alternative scenario to institution-based Technical and Vocational Education and Training (TVET), which many Malaysians are familiar with. A structured curriculum development of human resources learning needs according to the job profile of the typical individual and group work which will provide a clearer perspective on knowledge, competence and skill levels of employee behavior in performing tasks will be discussed. The biggest impact on this study is to produce high skill employees concerning customer satisfaction and increased organizational productivity towards high income nations.
\end{abstract}

\section{Human Resources Development and Education}

The development of skilled manpower is extremely needed and it is parallel to the industries demand. The review of the contemporary issues in Higher Education (HE) and Vocational Education and Training (VET) from a global perspective and identify principles and practices. Universities have evolved and expanded their identity by venturing into various concepts and style of administration, student attachment, funding and delivery. Considering the fact that this research explores the perspective of academics, this research will also consider the cultural environment of academics within the technical institute framework and industries.

The paper will also explore the position of mechanical technicians within the technical vocational training system and how they have evolved in relation to institutions. It is argued that the diversification of technical institution experienced by other countries would allow Malaysian higher education administrators to venture into a wider educational horizon mostly collaboration between industrial worker and technical instructor.
The discipline of HRD and adult education both consider the process of adult learning as being central to their theory and practice. Even so, the purpose of HRD and Adult Education differ, and their perspective on adult learning differs too [1]. The core differences is related to control of goals and purposes for which adult learning is employed - organizational versus individual control [2]. HRD professionals are in general agreement as to their goals. Most take the position that HRD should focus on increasing the performance requirements of its host organizations through the development of the organisation's work force $[1,3,4]$. Others believe HRD should focus on individual development and personal fulfilment without using organizational performance as the measure of worth [5]. It is the increase in performance resulting from HRD that justifies its existence. Consequently, it is the responsibility of HRD to focus on those goals as well as the goal of the individual employee.

If a nation can be perceived as a large organization that has a clear goal and objective, then it is possible to consider manpower planning that is designed to achieve the nation's goal and objective, then the whole adult learning process can be regarded as HRD. In this respect,

Corresponding author: zeti.kasman@gmail.com 
the Malaysian government has established a clear goal in its Vision 2020 announced by the Prime Minister in 1991. Thus the overall education and training can be categorised within the context of human resources development. As such, the Prime Minister's department outlined the concerted effort of the various organizations and ministries. This is explained in Figure 1:

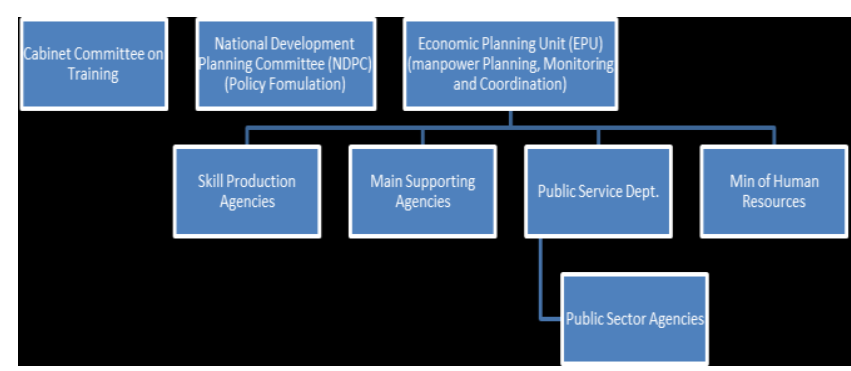

Figure 1: Human Resources Planning Machinery

There are two major organizations that share responsibilities in the development of human resources in the country. The Ministry of Education has full responsibilities on the education issues and encompasses the whole spectrum of education matters that include adult education particularly at universities and polytechnics. The Ministry of Human Resources (MoHR), together with few other ministries, is also actively involved in providing education and training but with more focus for adult VET. Therefore, this research wishes to explore the concern of 'power struggle' in educating and training, and try to examine the perception of academics about the matter.

\subsection{Work-based learning in TVET}

The term "work-based learning" is widely used in the literature. A general definition of work-based learning is "learning in the workplace, derived from work undertaken for or by an employer (i.e. in paid or unpaid work). It involves the gaining of competencies and knowledge in the workplace [6]. Other definitions of work-based learning are based on the context in which the term is used. For example, in higher education literature, especially from the UK, work-based learning refers to an approach for gaining academic qualifications through university-industry collaboration in which the university develops an academic program that is designed to meet the needs of a specific industry or organization [7-9].

Work-based learning may also refer to the blending of workplace experiences with traditional classroom-based educational programs. In this context, work-based learning may exist in various forms, such as practicums, internships, and service training [10]. At the university level, work-based learning is compulsory for certain degree programs, especially those leading to professions in medicine, law, and architecture. It is less common at the school level, except in the US, where work-based learning is an intervention for low-performing high schools [11].
In organizational learning literature, work-based learning is seen as important for bridging knowledge and action in the workplace [12]. Members of organizations need to learn so they can keep up with the pace of change in the modern world. As skills can quickly become obsolete, new skills need to be learned quickly, and the natural way to do so is to learn at work. The whole notion of skills as a set of technical abilities to perform a job has itself become obsolete. Replacing skills is the new idea of learning, which will be commingled with the notion of work itself. Those who support learning at work argue that it is important for enhancing productivity, competitiveness, and innovation [13, 14].

Integrating work-based learning into traditional classroom-based educational programs helps bridge the gap between universities and workplaces [15]. Formal education is seen as too theoretical; thus, gaining practical experience would help students in many ways. Supporters of work-based learning argue that it has a positive effect on learners' attitudes, aspirations, and performance [16]. There is evidence that work-based learning increases the number of employment opportunities for graduates $[17,18]$ and improves the starting salaries for high performing interns [19]. In addition to improving employability, work-based learning improves academic performance, leading to, for example, better grade point averages and honours [20, 21].

In TVET, work-based learning takes many forms, and its implementation varies from country to country [22]. At one end of the spectrum, there are informal apprenticeships, in which young individuals learn trades from more experienced craftsmen. This type of learning is common in less developed countries. As Sweet pointed out, these apprenticeships are unregulated and are not linked in any way to a formal TVET qualification system, but they are still an important source of skills and provide opportunities for young people to develop specialized skills.

At the other end of the spectrum are regulated frameworks, such as the German dual-training system. Here, work-based learning is linked to a TVET qualification system; apprentices who successfully go through the process will gain a recognized qualification. Between these two extremes are several variations of work-based learning within the TVET system. In the Malaysian TVET system, for example, which is largely institution-based, there is a compulsory portion of training in which students are required to learn within an actual workplace environment. For example, programs providing a Diploma Kemahiran Malaysia (Malaysian Skill Diploma) require that students undergo three months of industrial training in addition to institutionbased training.

Formal apprenticeships are also available. In Malaysia, two agencies run national-level apprenticeship schemes: Pembangunan Sumber Manusia Berhad (PSMB) and the Department of Skill Development (DSD). Both are agencies within the Ministry of Human Resources. PSMB's apprenticeship scheme has been in action for years, but its scope is limited because it covers only mechatronics, the hotel industry, woodworking, plastics 
injection molding, tool and die making, industrial sewing, and multimodal transport. The number of apprentices is also small. In 2014, PSMB approved 865 apprentices, which cost the government about RM 8 million, or roughly RM 9,250 per apprentice (Ministry of Human Resources, 2015). The DSD runs a much larger apprenticeship program, called the National Dual Training System (NDTS), which is modelled after the German dual system. In 2014, there were 11,271 apprentices at 1,083 companies throughout the country.

\section{Vocational Education Training at the Work Place}

Liberal education, conducting technical and vocational education is normally capital intensive and more expensive to maintain. VET institutions need to have machinery and equipment to begin with, a continuously require a constant supply of materials to be used in training. It was quite difficult to encourage their private investors to establish technical and vocational institutions.

In order to implement the strategy, Human Resources Development Council (HRDC) was established and they were tasked to manage of Human Resources Development Funds (HRDF). Briefly, an Act of the Malaysian Parliament has entrusted HRDC to collect a levy from Malaysian employers depending on the number of employees they employed. This levy was to be used by the contributing companies for the purpose of training [23]. Basically the contributing companies are not losing their money, but it is kept in the fund for their own benefit.

Since then, the number of companies mounting training programs has increased. Big corporation such as Proton Car Manufacturer, Motorola, Sony, Hitachi, Malaysia Airline and many other companies have embarked on establishing their own training divisions. Therefore, the work place has been actively involved in providing education and training, at least for their own employees.

\subsection{Improvement of Vocational Training System to Keep Meets with the Needs of Industries}

Malaysia has achieved very rapid development centred on manufacturing industries. Therefore, manpower needs have been on the increase and the quality of manpower has been changed as well. The government of Malaysia has focused on developing human resources of industries, because advancement of industries being capable of meeting international competition and development human resource of industries are prioritized in the Ninth Malaysia Plan (2006-2010), Tenth Malaysia Plan (2010-2015), and Third Industrial Master Plan (2006-2020). The government of Japan has supported CIAST (Center for Instructor and Advanced Skill Training) and JMTI (Japan-Malaysia Technical Institute), but human resources policy officials felt that ILJTM (Vocational training institutions under JTM) and others vocational training providers have been left behind the needs of industry and some policy intervention should be made for this matter. In order to cope with this issue, JICA (Japan International Cooperation Agency) dispatched a Japanese short-term expert of Labor Policy Advisor to MoHR (Ministry of Human Resource Development) in 2006. The expert conducted survey for one month in November 2006, for 2 months in January and April 2007 respectively. [2426]

Through the discussion with officers and training in Japan, officials of MoHR understood the following recognition how Japanese vocational training institutes catching up the needs of industries.

i. High priority on the curriculum which enables graduates to obtain knowledge, skills and attitude expected by employees.

ii. The collaboration between education/ training institutes and industries is very strong.

iii. The collaboration between education/ training institutes and community is very strong.

iv. Involvement of ex-graduates in student's career guidance.

v. Strong collaboration with secondary schools where their intakes come from.

MoHR officials drew a concept image showing the relation between vocational training institutes and industry, parents, teachers and ex-graduates as shown in the Figure 1 above. They named the concept of these collaborations as Community and Employment Support Services (CESS). The CESS concept was utilized to analyse the various activities.

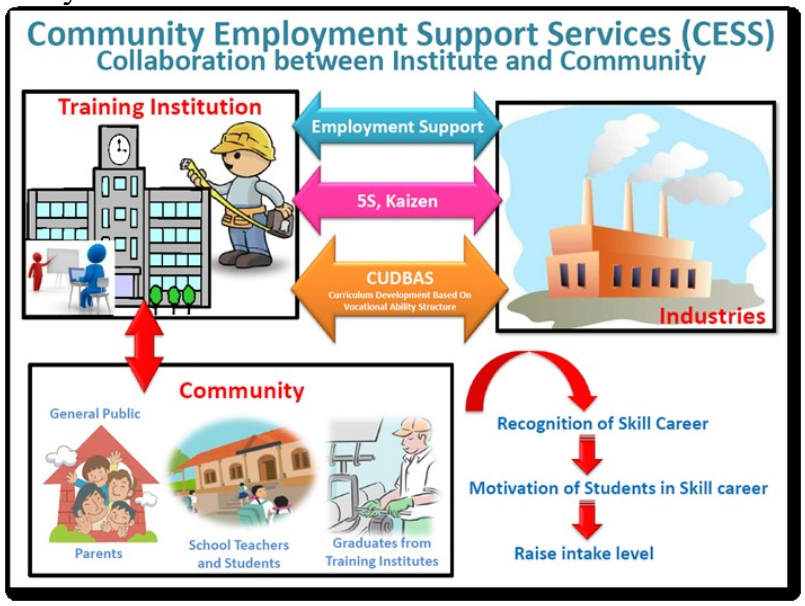

Figure 2: Relationship of Community, Vocational Training Institutes and Industries

Varieties of activities were identified such as employment support services, industry support, and management support as 5S/KAIZEN. 5S/KAIZEN has another role to improve the management of Vocational Training Institutes and at the same time, students are expected to learn practical implementation of $5 \mathrm{~S}$ activities to develop their awareness on human capital improvement. Employment supports consist of technique on produce a marketable student by designing 
employment activities such in terms on package the student before sent them to the industries [27].

\subsection{The Skill Training Fund Division}

The Skills Development Fund Division was established within the structure of the Human Resources Ministry in the year 2000. The setting up of the SDF was approved by Parliament on 14 December 2000 as a Trust Fund under Section 10 of the Financial Procedure Act 1957. The fund is specifically used for the purpose of providing loans for skills training. This division was entrusted to disburse loans from the Skill Development Funds (SDF) to student pursuing technical and vocational courses in public and private training institutions. This fund took effect from 2nd January 2001.

The loans will be given to Malaysian full time and part time students in public and private vocational and technical institutions. The maximum loan available is RM5000.00 per annum and will be for the duration of the accredited course. An administrative charge of $4 \%$ interest per annum will be levied on the loan which is payable over maximum period of fifteen years. Repayment of the fund has to commence within six month after the completion of the course or when the borrower starts working, whichever comes first. The Skills Development Fund was modelled along the conventional student loan in many other developed nations.

\subsection{Human Resources Development Council (HRDC)}

The Human Resources Development Council (HRDC) was established to encourage greater participation of industry to implement staff training. HRDC was given the task of collecting levy from companies, and the contributing companies used this fund for staff training. The HRDC was established under the Human Resources Development Act 1992. In 2001, the HRDC was corporatized and change its identity to the Human Resources Development Limited (Pembangunan Sumber Manusia Berhad). While continuing the same task, the PSMB is now focusing on skills upgrading of the workforce, to equip them with the latest knowledge and specializing in up-to date skills in manufacturing and service sector. The functions carried out by PSMB include assessing and determining the type and extent of employee training. With regard to financial assistance, PSMB also serves to determine the terms and conditions under which financial assistance or grant is to be given. [23]

\section{Continuing Professional Development (CPD)}

Continuing professional development (CPD), when provided formally, is something that is easy to recognize but perhaps rather more difficult to define. Theoretical and empirical argument surrounds the scope and understanding of the concept. Definition is made more subtle by the different conceptualisations in use but the common denominator is that CPD concerns practices aimed at employees' development beyond that derived from their initial training.

Employees are the prime movers or the main vehicles in producing the organization's objectives whom are not only skilful and competence in hands-on, but also academically. In facing the globalization challenges, it is the responsibilities of the employer to give a proper and effective input so that the outputs will be productive an in parallel to the industry's needs.

The effort to enrich the employee CPD in their skill, knowledge and attitude should be monitored by the employee. The achievement to higher level of performance will strengthen the level of confident for the employee to undergo the skill training.

Wider opportunities must be given to all employees to exhibit their performance and competencies so that they will be proofed to all kinds' of situations they might encounter and working comfortably. In addition, current policies and practices in CPD are frequently based on assumptions about learning and practice that are in urgent need of more empirical research [28].

Effective participation in contemporary, technologybased, knowledge society implies an increasing importance for voluntary learning and development by employees [29, 30].

Traditionally, further professional development was focused on education and training, in more or less formal classroom-based settings. Although problems regarding the transfer to the workplace of skills learned during training have been recognized [31], training is still assumed to be highly important for organizations [32].

Partly in reaction to the problem of transfer, the range of possible learning activities has been broadened over time and currently includes informal learning activities in the workplace as well as formal ones [33-35]. The workplace is a typical place where informal learning can occur, as the workplace context entails a wide range of more or less structured environments, which are only rarely organized with learning in mind [36]. The existence of informal learning opens up new avenues in research into learning [34].

Moreover, life-long learning or CPD is only possible where employees have systematic and valid information about their capabilities, that is to say, if they are able to form accurate self-perceptions, to carefully identify the qualities they need for future career success, and if they are able to adapt their behaviour accordingly $[37,38]$.

Recent literature on workplace learning emphasizes that both individual learning needs and collective prerequisites for learning should be taken into account simultaneously if the learning is to be successful [39-41]. Consequently, individual motivation and the will to learn or develop oneself alone do not guarantee CPD. Or the 
other way around, opportunities for development offered by the employer and one's working organization do not necessarily lead to sought outcomes [42].

In addition to formal training activities, work organizations can facilitate employees' CPD by providing a climate that encourages individual development and change and by providing ample opportunities for informal learning [43]. In a similar vein, an organizational structure which allows experience-based learning at work [44].

Defining CPD broadly is not only a question of how to organize training and education for professionals to develop their professional skills and competencies, but also how to identify competent and skilled professionals as part of their working community [45]. Once we have a better understanding of CPD, quantitative approaches using psychometrically sound (reliable and valid) measures can be used to determine CPD practices, determinants and outcomes, in terms of both individual career success and organizational performance.

CPD could be defined as learning which takes place in workplaces and organizations but we enter a caveat here because so much of the research appears to be in the health services and teaching and these professions may not necessarily be an accurate paradigm for professional work more generally. They are often characterized by large, hierarchical organizations in the public sector operating within quite detailed government policy guidelines. Therefore, CPD needs to be more strongly linked with organizational HRD practices and organizational learning as a whole as well as with developments at the level of the profession. Thus, more studies and practical innovations are needed to build on workplace learning pedagogies or even a workplace curriculum as part of organizations' HRD practices and to examine how these relate to developments at the level of the profession.

\subsection{The Capability Approach}

The economic growth is an insufficient indicator for individuals' quality of life. This is because information on economic growth alone will not help us understand the barriers in our society to achieving equity for all members of society; a better indicator would be "human capabilities." The word "capabilities" refers to what people are able to be and do, rather than how much income or how many material goods they possess.

In the capability-based assessment of justice, individual claims are not to be assessed in terms of the resources or primary goods the persons respectively hold, but the freedoms they actually enjoy to choose the lives that they have reasons to value [46].

The core idea of the Capability Approach is that individuals should have the freedom to do what they value, or in other words, to live a life that they have reasons to value. There are three important concepts in the Capability Approach: capability, functioning, and agency. Capability is one's potential capacity, functioning is one's actual or the realized capacity, and agency is one's personal freedom to decide whether or not to use a particular capability. Individuals need resources in order to convert capability into functioning. These resources include the goods they possess and the services they have access to. Examples of resources are academic qualifications, paid employment, and education and training.

However, the extent to which individuals can generate capabilities from resources is influenced by personal, social, and environmental factors, called conversion factors [47]. Personal conversion factors include one's physical condition, literacy, and intelligence. Social conversion factors include public policies, social norms, discriminating practices, gender roles, societal hierarchies, and power relations. Environmental conversion factors include climate, geographical location, infrastructure, transportation systems, and communication systems.

Given its emphasis on expanding people's freedoms and capabilities to live a life of their own choosing, the capabilities approach offers a promising basis upon which worker wellbeing can be enhanced. The capabilities approach would ask how workers' freedom to achieve wellbeing can be increased, which transcends simply asking how resources may be distributed or how happy or content workers feel [48].

The Capability Approach was only recently suggested as an alternative philosophical or theoretical underpinning for TVET. The view that TVET is linked to productivity and economic development, writing that the current approach to TVET is "grounded in an outmoded model of development". He goes on to suggest several alternative philosophies to TVET, including the Capability Approach, the human rights approach, and the integrated human development approach [49].

Table 2. Valued capabilities at the workplace

\begin{tabular}{|c|c|}
\hline Capabilities* & Work capability list** \\
\hline $\begin{array}{l}\text { The capability to be } \\
\text { alive, to have } \\
\text { physical security, and } \\
\text { to be healthy }\end{array}$ & $\begin{array}{l}\text { - Work that is safe and healthy in the } \\
\text { short and long term } \\
\text { - Workplace that is free from } \\
\text { harassment and unfair } \\
\text { - discrimination }\end{array}$ \\
\hline $\begin{array}{l}\text { The capability to be } \\
\text { knowledgeable, to } \\
\text { understand and } \\
\text { reason, and to have } \\
\text { the skills needed to } \\
\text { participate in society }\end{array}$ & $\begin{array}{l}\text { - Work that lets you develop your } \\
\text { skills and abilities } \\
\text { - Work where you receive the } \\
\text { training you need to do the job } \\
\text { effectively } \\
\text { - Work with good communication } \\
\text { among the people with whom you } \\
\text { work } \\
\text { - Work that uses your skills, } \\
\text { knowledge and experience } \\
\text { - Work hours that let you participate } \\
\text { in the community }\end{array}$ \\
\hline $\begin{array}{l}\text { The capability to } \\
\text { enjoy a comfortable } \\
\text { standard of living, } \\
\text { with independence } \\
\text { and security }\end{array}$ & $\begin{array}{l}\text { - Work that pays well } \\
\text { - Work with good job security } \\
\text { - Work where the people you work } \\
\text { for treat you with respect }\end{array}$ \\
\hline
\end{tabular}




\begin{tabular}{|c|c|}
\hline Capabilities* & Work capability list** \\
\hline $\begin{array}{l}\text { The capability to } \\
\text { engage in productive } \\
\text { and valued activities }\end{array}$ & $\begin{array}{l}\text { - Work that is interesting } \\
\text { - Work where the people you work } \\
\text { with are friendly and helpful } \\
\text { - Work that gives you a sense of } \\
\text { accomplishment } \\
\text { - Work for which you receive } \\
\text { recognition } \\
\text { - Work where your chances of career } \\
\text { advancement are good }\end{array}$ \\
\hline $\begin{array}{l}\text { The capability to } \\
\text { enjoy personal, } \\
\text { family and social life }\end{array}$ & $\begin{array}{l}\text { Work that allows you to balance } \\
\text { your work, family and personal life }\end{array}$ \\
\hline $\begin{array}{l}\text { The capability to } \\
\text { participate in decision } \\
\text { making and, have an } \\
\text { influence }\end{array}$ & $\begin{array}{l}\text { Work that allows you freedom to } \\
\text { do your job - Work where you can } \\
\text { choose your own schedule within } \\
\text { established limits } \\
\text { - Work that allows you to participate } \\
\text { in decision-making } \\
\text { - Work that allows you to form and } \\
\text { join civil organizations and } \\
\text { solidarity groups, including trade } \\
\text { unions } \\
\text { - Work that allows you to participate } \\
\text { in the local community }\end{array}$ \\
\hline $\begin{array}{l}\text { The capability to be } \\
\text { and express yourself, } \\
\text { have self-respect, and } \\
\text { know you will be } \\
\text { protected and treated } \\
\text { fairly by the law }\end{array}$ & $\begin{array}{l}\text { Work where the people you work } \\
\text { for treat you with respect }\end{array}$ \\
\hline
\end{tabular}

\section{Past studies on work-based learning and ccompetencies}

At the time this study was carried out, there were no studies utilizing Sen's Capability Approach to examine work-based learning among Malaysian workers. There are, however, several studies on training for industry workers. When discussing training for workers (whether vocational training, on-the-job training, formal training, informal training, etc.), the few articles on work-based training that are available usually emphasized the perspective of management $[52,53]$. Studies that present ordinary workers' training stories are lacking.

There are some studies that try to present workers' views on certain issues. For example, Abdul Aziz et al. (2008) studied the views of ex-trainees from an electrical wiring course regarding whether the vocational training they received meets industrial needs [54]. Additionally, Muhamad and Idris studied learners' perspective on workplace learning, covering workers from various sectors in Malaysia. So far, the researcher has found no studies that discuss vocational training from the perspective of capability development for Malaysian workers [55]. It was estimated that about $64 \%$ of the Malaysian workforce has only an SPM qualification or lower [56]. This implies that many young Malaysians enter the job market without any post-secondary education or training. They had to acquire vocational knowledge and skills at the workplace. Although the acquisition of vocational skills at the workplace is common, the researcher found no studies on how workers' capabilities are developed at the workplace through vocational training. This particular gap will be addressed through this research.

Internationally, some studies have looked at TVET from a capability perspective of South African students at a vocational college. According to Powell, the education received by students at this vocational college gave them the "capability to aspire," or to dream and make plans about something that was previously unimaginable.

\section{Methodology}

The methodology which will be adopted in this study is to identify the competencies of the mechanical industries employees'. This stage begins with identifying problems followed by setting objectives of the study. Having all the objectives in place, related literatures were reviewed to build up knowledge and ideas on the topic. Further, the topic was reviewed in view of the objectives set to ensure the data collection study is in line with the objectives set and within the scope of the topic.

Reviews of previous studies were used in supporting to specify the improvement plan according to the issues faced. This paper used a document analysis technique of the important documents from Ministry of Human Resources called Curriculum Development Based on Ability Structure (CUDBAS) methodology. The competency chart, competency map and training development plan will be created according to the specific job position to the industries. The competency checklist will be used during pre and post survey as a data collection. Response from the competency map will be analysing based on the study objectives. A review of job competencies and the landscape of TVET in Malaysia mainly aimed that contribute to the improvement of mechanical industries employees'. In this study, data analysis planned to be performed concurrently with data collection to examine the data.

\section{Conclusions}

This study is concerned with the development of TVET in Malaysia for it has significant contribution in nation building. It is a fact, that TVET is within the subset of education and its development has to be in relation to its surrounding within educational sector. Though these study, it began with hypothesis that HRD to participate in VET development. The shortage of quality workforce experienced by Malaysian economy during the economic booming in late 80 s and early 90 s clearly provide lesson to policy makers that VET is obviously in need for better attention for development. Collaboration and means has to be explored, to capitalise these strengths and improve the weaknesses.

Trends that are relevant to the issues addressed by this study in particular regarding the issue of CPD of training competencies for Malaysian Mechanical Industries, human resources development, vocational 
education training at workplace and capability approach. All these issues were closely related to develop the career path in mechanical industries. In this respect, there has been clear diversification and changes in up to date industries and technologies in term of their concept of establishment in order to maintain a continuous response to the external environment. The recent trend on the competencies development frameworks is considered as effective mechanism to bring closer relationship or connection between the resources and industries.

\section{References}

1. Swanson, R.A., Human Resource Development: Performance Is The Key. 1995.

2. Knowles, M., Holton, E. F., \& Swanson, R. A., The adult learner: The definitive classic in adult education and human resource development. 1998.

3. Knowles, M., The adult learner. A neglected species. 4th ed. 1990.

4. McLagan, P., Models for HRD practice. 1989.

5. Dirkx, J.M., Transformative Learning Theory in the Practice of Adult Education: An Overview. 1996.

6. Connor, H. (2005). Work-based learning: a consultation. London: Council for Industry and Higher Education.

7. Foster, E., \& Stephenson, J. (1998). Work-based learning and universities in the U.K.: a review of current practice and trends. Higher Education Research \& Development, 17(2), 155-170.

8. Garnett, J. (2001). Work based learning and the intellectual capital of universities and employers. The Learning Organization, 8(2), 78-82.

9. Courtney, J., Long, J., \& Hall, D. (2013). Workbased learning partnerships: a case of learning and talent management intervention for developing future leaders and managers. HR Bulletin: Research and Practice, 8 (2). 13-18.

10. Sattler, P., \& Peters, J. (2013). Work-integrated learning in Ontario's postsecondary sector: The experience of Ontario graduates. Toronto: Higher Education Quality Council of Ontario.

11. Herlihy, C.M., \& Quint, J. (2006). Emerging evidence on improving high school student achievement and graduation rates: the effects of four popular improvement programs. Washington: National High School Center. Retrieved December 28, 2015 from http://files.eric.ed.gov/fulltext/ED501076.pdf

12. Raelin, J.A. (2008). Work-based learning: Bridging knowledge and action in the workplace. San Francisco, CA: Jossey-Bass.

13. Fenwick, T. (2003). Innovation: examining workplace learning in new enterprises. Journal of Workplace Learning, 15(3), 123-132.

14. Høyrup, S. (2010). Employee-driven innovation and workplace learning: basic concepts, approaches and themes. Transfer: European Review of Labour and Research, 16(2), 143-154.

15. Hills, J.M., Robertson, G., Walker, R., Adey, M.A., \& Nixon, I. (2003). Bridging the gap between degree programme curricula and employability through implementation of work-related learning. Teaching in Higher Education, 8(2), 211-231.

16. Taylor, J.C. (1997). Learning at work in a workbased welfare system: opportunities and obstacles: Lessons from the school-to-work experience. Boston, MA: Jobs for the Future. Retrieved December 25, 2015 from http://www.jff.org/sites/default/files/publications/Lr ngatWork.pdf

17. Callanan, G., \& Benzing, C. (2004). Assessing the role of internships in the career-oriented employment of graduating college students. Education + Training, 46(2), 82-89.

18. Huq, A., \& Gilbert, D.H. (2013). Enhancing graduate employability through work-based learning in social entrepreneurship: A case study. Education + Training, 55(6), 550-572.

19. Gault, J., Leach, E., \& Duey, M. (2010). Effects of business internships on job marketability: the employers' perspective. Education + Training, 52(1), 76-88.

20. Blair, B.F., \& Millea, M. (2004). Student academic performance and compensation: The impact of cooperative education. College Student Journal, 38(4), 643-652.

21. Rawlings, P., White, P., \& Stephens, R. (2005). Practice-based learning in information systems: the advantages for students. Journal of Information Systems Education, 16(4), 455-464.

22. Sweet, R. (2013). Work-based learning: Why? How? In K Ananiadou, (Ed.), Revisiting global trends in TVET: reflections on theory and practice (pp. 164-203) Bonn, Germany: UNESCOUNEVOC. Retrieved June 20, 2014 from http://unevoc.unesco.org/fileadmin/up/2013_epub_r evisiting_global_tre nds_in_tvet_book.pdf

23. (HRDC), H.R.D.C. Akta Pembangunan Sumber Manusia 1992. 2013.

24. Plan, T.M. 2010-2015, Percetakan Negara Malaysia.

25. Plan, T.I.M. 2006-2020, Percetakan Negara Malaysia.

26. Human Resource Development Policy. 2007.

27. Manpower Department, M.o.H.R., Community Employment \& Support Services - 'Improvement of Vocational Training System to Keep Meet with the Needs of Industries'. 2010.

28. Kilminster, S., Bradburg, H., Frost, N. and Zukas, M. (2012), 'Critical perspectives on professional lifelong learning', Studies in Continuing Education, $34,1,1-4$.

29. Evers, A. T., Van der Heijden, B. I. J. M., Kreijns, K. and Gerrichhauzen, J. T. G. (2011b), 'Organisational factors and Teachers' Professional 
Development in Dutch secondary Schools', Journal of European Industrial Training, 35, 1, 24-44.

30. Maurer, T. J. (2002), 'Employee learning and development orientation: toward an integrative model of involvement in continuous learning', Human Resource Development Review, 1, 1, 9-44.

31. Baldwin, T. T. and Ford, J. K. (1988), 'Transfer of training: a review and directions for future research', Personnel Psychology, 41, 1, 63-105.

32. Smith, E., Smith, A., Pickersgill, R. and Rushbrook, P. (2006), 'Qualifying the workforce. The use of nationally-recognised training in Australian companies', Journal of European Industrial Training, 30, 8, 592-607.

33. Cheetham, G. and Chivers, G. (2001), 'How professionals learn in practice: an investigation of informal learning amongst people working in professions', Journal of European Industrial Training, 25, 5, 248-92.

34. Eraut, M. (2004), 'Informal learning in the workplace', Studies in Continuing Education, 26, 2, 247-73.

35. Marsick, V. J. and Watkins, K. E. (2001), 'Informal and incidental learning', New Directions for Adult and Continuing Education, 89, 25-34.

36. Evers, A. T., Kreijns, K., Van der Heijden, B. I. J. M. and Gerrichhauzen, J. T. G. (2011a), 'An organizational and task perspective model aimed at enhancing Teachers' Professional Development and occupational expertise', Human Resource Development Review, 10, 2, 151-79.

37. Van der Heijde, C. M. and Van der Heijden, B. I. J. M. (2006), 'A competence-based and multidimensional operationalization and measurement of employability', Human Resource Management, 45, 3, 449-76.

38. Van der Heijden, B. I. J. M., De Lange, A. H., Demerouti, E. and Van der Heijde, C. M. (2009a), 'Employability and career success across the lifespan. Age effects on the employability-career success relationship', Journal of Vocational Behavior, 74, 156-64.

39. Collin, K. (2006), 'Connecting work and learning design engineers' learning at work', Journal of Workplace Learning, 18, 7/8, 403-13.

40. Fuller, A. and Unwin, L. (2004), 'Expansive Learning Environments: Integrating Organizational and Personal Development', in H. Rainbird, A. Fuller and A. Munro (eds), Workplace Learning in Context (London: Routledge), pp. 126-44.

41. Hodkinson, P., Biesta, G. and James, D. (2008), 'Understanding learning culturally: overcoming the dualism between social and individual views of learning', Vocations and Learning, 1, 1, 27-47.

42. Collin, K. (2009), 'Work-related identity in individual and social learning at work', Journal of Workplace Learning, 21, 1, 23-35.
43. Bartram, D., Foster, J., Lindley, P. A., Brown, A. J. and Nixon, S. (1993), Learning Climate Questionnaire (LCQ): Background and Technical Information (Oxford: Employment Service and Newland Park).

44. Wexlberger, L. P. (1993), 'Lernen im Arbeitsprozeß [Learning in the Labour Process]', in C. Heidack (ed.), Lernen der Zukunft. Kooperative Selbstqualifikation - die effektivste Form der Ausund Weiterbildung im Betrieb (München: Lexika), pp. 299-310.

45. Billett, S., Harteis, C. and Eteläpelto, A. (eds) (2008), Emerging Perspectives of Workplace Learning (Rotterdam: Sense Publishers).

46. Sen, A. (1992). Inequality re-examined. Oxford, UK: Oxford University Press.

47. Anand, P., Hunter, G., \& Smith, R. (2005). Capabilities and well-being: evidence based on the Sen-Nussbaum approach to welfare. Social Indicators Research, 74(1), 9-55.

48. Anand, P., Hunter, G., Carter, I., Dowding, K., Guala. F., \& Van Hees, M. (2009). The development of capability indicators. Journal of Human Development and Capabilities, 10(1), 125152.

49. Vizard, P., \& Burchardt, T. (2007). Developing a capability list: Final recommendation of the Equalities Review Steering Group on Measurement. Case Paper 121, Centre for Analysis of Social Exclusion, London School of Economics.

50. Bryson, J. (2013). Putting skill in its place. Journal of Education and Work, doi:10.1080/13639080. 2013.835794

51. Lambert, M., Vero, J., \& Zimmermann, B. (2012). Vocational training and professional development: a capability perspective. International Journal of Training and Development, 16(3), 164-182.

52. Hooi, L.W. (2010). Technical training in the MNCs in Malaysia: a case study analysis of the petrochemical industry. Journal of European Industrial Training, 34(4), 317-343.

53. Hamzah, A., \& Ho, S. (1994). TQM training for small and medium industries in Malaysia. Training for Quality, 2(2), 27-35.

54. Abdul-Aziz, A.R., Jaafar, M., Enshassi, A., \& Mohamed-Salleh, M.N. (2008). Does vocational training meet the construction industry needs in Malaysia? Feedback from ex-trainees of the basic electrical wiring course from one training institution. Journal of Engineering, Design and Technology, 6(3), 258268.

55. Muhamad, M., \& Idris, K. (2005). Workplace learning in Malaysia: the learner's perspective. International Journal of Training and Development, 9(1), 62-78.

56. Department of Statistics (2010). Labour Force Statistics, Malaysia, 2010. 